\title{
A Modified Method to Generate Typical Meteorological Years from the Long-Term Weather Database
}

\author{
Haixiang Zang, ${ }^{1}$ Qingshan $\mathrm{Xu},{ }^{1}$ Pengwei $\mathrm{Du},{ }^{2}$ and Katsuhiro Ichiyanagi ${ }^{3}$ \\ ${ }^{1}$ School of Electrical Engineering, Southeast University, Nanjing 210096, China \\ ${ }_{2}^{2}$ Pacific Northwest National Laboratory, P.O. Box 999, Richland, WA 99352, USA \\ ${ }^{3}$ Department of Electrical and Electronics Engineering, Aichi Institute of Technology, 1247 Yachigusa, Yakusa-cho, \\ Toyota, Aichi 470-0392, Japan \\ Correspondence should be addressed to Haixiang Zang, zanghaixiang@seu.edu.cn \\ Received 11 August 2011; Revised 20 October 2011; Accepted 31 October 2011 \\ Academic Editor: Junwang Tang
}

Copyright (๑) 2012 Haixiang Zang et al. This is an open access article distributed under the Creative Commons Attribution License, which permits unrestricted use, distribution, and reproduction in any medium, provided the original work is properly cited.

A modified typical meteorological year (TMY) method is proposed for generating TMY from practical measured weather data. A total of eleven weather indices and novel assigned weighting factors are applied in the processing of forming the TMY database. TMYs of 35 cities in China are generated based on the latest and accurate measured weather data (dry bulb temperature, relative humidity, wind velocity, atmospheric pressure, and daily global solar radiation) in the period of 1994-2010. The TMY data and typical solar radiation data are also investigated and analyzed in this paper, which are important in the utilizations of solar energy systems.

\section{Introduction}

China lies in the northeast part of East Asia between $4^{\circ}$ and $53^{\circ}$ North latitude and $73-135^{\circ}$ East longitude with a population of about 1.3 billion $[1,2]$. China, as the largest developing country, is the second largest country in energy consumption [3]. To relieve the dual pressure from rising energy demand and growing environmental problems, renewable energy sources are considered for satisfying a significant part of the energy demand in China [4-6]. As one of the renewable energy, solar energy is a clean energy source and is extremely abundant in China. More than two-thirds of China receives an annual total solar radiation above $5.9 \mathrm{GJ} / \mathrm{m}^{2}$ $\left(1639 \mathrm{kWh} / \mathrm{m}^{2}\right)$ with more than $2200 \mathrm{~h}$ of sunshine per year [7-9]. On the other hand, solar radiation is the fuel of solar energy systems. Solar radiation data are the basic and key parameters in the applications of solar energy systems [9$11]$.

Since solar radiation data can vary from year to year, there is a need to generate a customized solar radiation database that can well represent the long-term averaged soar radiation over a year $[12,13]$. Representative databases for one year duration, known as typical meteorological year (TMY)
[14], are often employed for computer simulations of solar energy conversion systems and building systems. Based on the TMY method, typical solar radiation data are formed by the selection from the real recorded weather data.

In the past, several methodologies [15-20] for forming TMYs have been reported, such as Sandia method, FestaRatto method, and Danish method. Among the different, TMY generation methods, the Sandia method is widely adopted. Hall et al. [19], Said and Kadry [21], Marion and Urban [22], Petrakis et al. [23], Kalogirou [24], Chow et al. [25], Wilcox and Marion [26], Yang et al. [27], and Jiang [14] generated TMYs for different locations with different weather parameters and assigned weighting factors. These methods in above literatures are in fact similar, the main differences lie in the numbers of daily indices (weather indices) to be included and their assigned weightings [25].

A few studies for selecting TMYs in China have been found in recent years. In the paper authored by Chow et al. [25], typical weather year files for Hong Kong and Macau were produced and analyzed. Zhou et al. [9] developed typical solar radiation years and typical solar radiation data for 30 meteorological stations in China only using the longterm daily global solar radiation records. In the paper of 
Yang et al. [27], TMYs for 60 cities in five major climatic zones of China were investigated through nine recorded weather indices (only the global solar radiation and not including the direct solar radiation data). But the data of the nine measured weather indices are before the year of 2000 . Jiang [14] generated TMYs using nine weather parameters (including the global and the direct solar radiation data). However, only eight cities were considered and generated.

It is suggested that the TMY selection process should include the most recent meteorological observations [25]. In this present study, based on the modified TMY method (eleven meteorological indices and the novel assigned weighting factors), the TMYs and typical solar radiation data for 35 stations are formed and analyzed using the latest and accurate long-term weather data.

\section{Selection of Cities and Data Used}

In order to organize and generate the TMY database, the daily weather data are required. The available weather data are managed and provided by China meteorological stations. Due to space limitation, 35 cities having the local meteorological stations are investigated and selected. These stations cover latitudes range from $18^{\circ} 14^{\prime} \mathrm{N}$ (Sanya) to $53^{\circ} 28^{\prime} \mathrm{N}$ (Mohe), longitudes from $75^{\circ} 59^{\prime} \mathrm{E}$ (Kashgar) to $130^{\circ} 17^{\prime} \mathrm{E}$ (Jiamusi) and have considerably varied altitude from $2.5 \mathrm{~m}$ (Tianjin) to $4507 \mathrm{~m}$ (Nagqu). All the complex climates within China are represented in the cities, and the relevant information for the 35 stations is shown in Table 1.

In view of the actual situation in China and the characteristics of solar energy systems, eleven meteorological indices are applied in this paper. These weather indices are maximum, minimum, and mean dry-bulb temperature; minimum and mean relative humidity; maximum and mean wind velocity; maximum, minimum, and mean atmospheric pressure; daily global solar radiation. In addition, the relative errors of global solar radiation recorded data are changed from $\pm 10 \%$ to $\pm 0.5 \%$ since 1993 owing to new observation instrument in China meteorological stations. So, the most recent and accurate weather data during the periods between 1994 and 2010 are chosen and gathered for the present research.

The missing and invalid measurements, accounting for $0.38 \%$ of the whole database, are marked and coded as 32744 or 32766 in the data. Moreover, these problematical data are replaced by the values of previous or subsequent days using the interpolation method [15]. In the data processing, if more than 5 days measured data are not available in a month, the month is eliminated from the database.

\section{Method Used}

The Typical Meteorological Year (TMY) method, developed by Sandia National Laboratories, is selected and modified in this paper [19]. It is one of the most widely adopted methodologies for combining 12 typical meteorological months (TMMs) from different years over the available period to form a complete year. The procedure for selecting the 12 TMMs consisted of two steps.

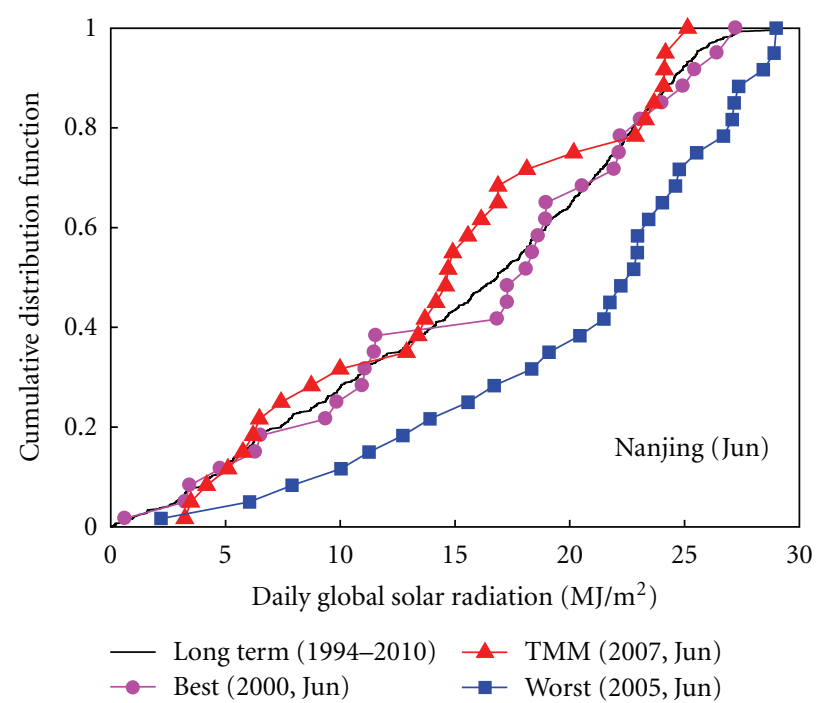

FIgURE 1: CDFs for June daily global solar radiation for Nanjing.

3.1. Selection of Five Candidate Years. According to the Finkelstein-Schafer statistic [28], if a number, $n$, of observations of a weather index $x$ are available and have been sorted into an increasing order $x_{1}, x_{2}, \ldots, x_{n}$, the cumulative distribution function (CDF) for this weather index is determined by a monotonic increasing function $\operatorname{CDF}(x)$. The formula of function $\operatorname{CDF}(x)$ is given as follows:

$$
\operatorname{CDF}(x)= \begin{cases}0 & \text { for } x<x_{1} \\ \frac{(i-0.5)}{n} & \text { for } x_{i} \leq x<x_{i+1} \\ 1 & \text { for } x \geq x_{n}\end{cases}
$$

The FS comparison statistics between the long-term CDF for each month and the CDF for each individual year of the month are calculated by the following equation:

$$
\mathrm{FS}_{x}(y, m)=\frac{1}{N} \sum_{i=1}^{N}\left|\mathrm{CDF}_{m}\left(x_{i}\right)-\mathrm{CDF}_{y, m}\left(x_{i}\right)\right|,
$$

where $\mathrm{FS}_{x}(y, m)$ is $\mathrm{FS}(y, m)$ statistics for each weather index $x$ ( $y$ means year and $m$ means month); $\mathrm{CDF}_{m}$ is the longterm and $\mathrm{CDF}_{y, m}$ is the short-term (for the year $y$ ) cumulative distribution function of the weather index $x$ for month $m ; N$ is the number of daily readings of the month (e.g., for January, $N=31$ ).

Based on the FS statistic and the meteorological database used in this work, the CDF curves of daily global solar radiation (DGSR) for the months of June and December (choosing Nanjing as an example) are shown in Figures 1 and 2. It can be concluded that the short-term CDFs follow quite closely their long-term counterparts. In Figure 1, the CDF of DGSR for June 2000 is most similar to the long-term CDF (smallest value of FS statistic), while the CDF of DGSR for June 2005 is least similar (largest value of FS statistic). Likewise, in Figure 2, the DGSR CDF for December of 2006 is closest to the long-term CDF, while the DGSR CDF for December of 2010 is most dissimilar. Even though they are 
TABLE 1: Geographical locations and data period of the meteorological stations used for this study.

\begin{tabular}{|c|c|c|c|c|c|c|}
\hline Number & Location & $\begin{array}{l}\text { Latitude } \\
(\mathrm{N})\end{array}$ & $\begin{array}{l}\text { Longitude } \\
\text { (E) }\end{array}$ & $\begin{array}{c}\text { Elevation } \\
(\mathrm{m})\end{array}$ & Period & Total years \\
\hline 1 & Beijing & $39^{\circ} 48^{\prime}$ & $116^{\circ} 28^{\prime}$ & 31.3 & 1994-2010 & 17 \\
\hline 2 & Changchun & $43^{\circ} 54^{\prime}$ & $125^{\circ} 13^{\prime}$ & 236.8 & 1994-2010 & 17 \\
\hline 3 & Changsha & $28^{\circ} 13^{\prime}$ & $112^{\circ} 55^{\prime}$ & 68 & 1994-2010 & 17 \\
\hline 4 & Chengdu & $30^{\circ} 40^{\prime}$ & $104^{\circ} 01^{\prime}$ & 506.1 & 1994-2003 & 10 \\
\hline 5 & Dongsheng & $39^{\circ} 50^{\prime}$ & $109^{\circ} 59^{\prime}$ & 1460.4 & 1994-2010 & 17 \\
\hline 6 & Fuzhou & $26^{\circ} 05^{\prime}$ & $119^{\circ} 17^{\prime}$ & 84 & 1994-2010 & 17 \\
\hline 7 & Guangzhou & $23^{\circ} 10^{\prime}$ & $113^{\circ} 20^{\prime}$ & 41 & 1994-2010 & 17 \\
\hline 8 & Guiyang & $26^{\circ} 35^{\prime}$ & $106^{\circ} 44^{\prime}$ & 1223.8 & 1994-2010 & 17 \\
\hline 9 & Haikou & $20^{\circ} 02^{\prime}$ & $110^{\circ} 21^{\prime}$ & 13.9 & 1994-2010 & 17 \\
\hline 10 & Hami & $42^{\circ} 49^{\prime}$ & $93^{\circ} 31^{\prime}$ & 737.2 & $1994-2010$ & 17 \\
\hline 11 & Hangzhou & $30^{\circ} 14^{\prime}$ & $120^{\circ} 10^{\prime}$ & 41.7 & 1994-2010 & 17 \\
\hline 12 & Harbin & $45^{\circ} 45^{\prime}$ & $126^{\circ} 46^{\prime}$ & 142.3 & 1994-2010 & 17 \\
\hline 13 & Hefei & $31^{\circ} 52^{\prime}$ & $117^{\circ} 14^{\prime}$ & 27.9 & $1994-2010$ & 17 \\
\hline 14 & Jiamusi & $46^{\circ} 49^{\prime}$ & $130^{\circ} 17^{\prime}$ & 81.2 & 1994-2010 & 17 \\
\hline 15 & Jinan & $36^{\circ} 36^{\prime}$ & $117^{\circ} 03^{\prime}$ & 170.3 & $1994-2010$ & 17 \\
\hline 16 & Kashgar & $39^{\circ} 28^{\prime}$ & $75^{\circ} 59^{\prime}$ & 1288.7 & $1994-2010$ & 17 \\
\hline 17 & Kunming & $25^{\circ} 01^{\prime}$ & $102^{\circ} 41^{\prime}$ & 1892.4 & 1994-2010 & 17 \\
\hline 18 & Lanzhou & $36^{\circ} 03^{\prime}$ & $103^{\circ} 53^{\prime}$ & 1517.2 & 1994-2003 & 10 \\
\hline 19 & Lhasa & $29^{\circ} 40^{\prime}$ & $91^{\circ} 08^{\prime}$ & 3648.7 & $1994-2010$ & 17 \\
\hline 20 & Mohe & $53^{\circ} 28^{\prime}$ & $122^{\circ} 31^{\prime}$ & 433 & $1997-2010$ & 14 \\
\hline 21 & Nagqu & $31^{\circ} 29^{\prime}$ & $92^{\circ} 04^{\prime}$ & 4507 & 1994-2010 & 17 \\
\hline 22 & Nanchang & $28^{\circ} 36^{\prime}$ & $115^{\circ} 55^{\prime}$ & 46.7 & 1994-2010 & 17 \\
\hline 23 & Nanjing & $32^{\circ} 00^{\prime}$ & $118^{\circ} 48^{\prime}$ & 7.1 & 1994-2010 & 17 \\
\hline 24 & Nanning & $22^{\circ} 38^{\prime}$ & $108^{\circ} 13^{\prime}$ & 121.6 & 1994-2010 & 17 \\
\hline 25 & Sanya & $18^{\circ} 14^{\prime}$ & $109^{\circ} 31^{\prime}$ & 5.9 & $1994-2010$ & 17 \\
\hline 26 & Shanghai & $31^{\circ} 24^{\prime}$ & $121^{\circ} 29^{\prime}$ & 6 & $1994-2010$ & 17 \\
\hline 27 & Shenyang & $41^{\circ} 44^{\prime}$ & $123^{\circ} 27^{\prime}$ & 44.7 & $1994-2010$ & 17 \\
\hline 28 & Taiyuan & $37^{\circ} 47^{\prime}$ & $112^{\circ} 33^{\prime}$ & 778.3 & 1994-2010 & 17 \\
\hline 29 & Tianjin & $39^{\circ} 05^{\prime}$ & $117^{\circ} 04^{\prime}$ & 2.5 & 1994-2010 & 17 \\
\hline 30 & Urumqi & $43^{\circ} 47^{\prime}$ & $87^{\circ} 39^{\prime}$ & 935 & $1994-2010$ & 17 \\
\hline 31 & Wuhan & $30^{\circ} 37^{\prime}$ & $114^{\circ} 08^{\prime}$ & 23.1 & 1994-2010 & 17 \\
\hline 32 & Xian & $34^{\circ} 18^{\prime}$ & $108^{\circ} 56^{\prime}$ & 397.5 & 1994-2004 & 11 \\
\hline 33 & Xining & $36^{\circ} 43^{\prime}$ & $101^{\circ} 45^{\prime}$ & 2295.2 & $1994-2010$ & 17 \\
\hline 34 & Yinchuan & $38^{\circ} 29^{\prime}$ & $106^{\circ} 13^{\prime}$ & 1111.4 & $1994-2010$ & 17 \\
\hline 35 & Zhengzhou & $34^{\circ} 43^{\prime}$ & $113^{\circ} 39^{\prime}$ & 110.4 & 1994-2010 & 17 \\
\hline
\end{tabular}

not the best months, respect to the long-term CDF, June of 2007 and December of 1998 are finally selected as the TMM for June and December, respectively. This is a consequence of additional selection steps described in the following.

For each of the candidate months, the FS statistics of the eleven weather indices are grouped into a composite weighted sum (WS) by (3). Moreover, the five years with the smallest WS values are selected as the candidate years

$$
\mathrm{WS}(y, m)=\frac{1}{M} \sum_{x=1}^{M} \mathrm{WF}_{x} \cdot \mathrm{FS}_{x}(y, m)
$$

where $\operatorname{WS}(y, m)$ is the average weighted sum for the month $m$ in the year $y$; $\mathrm{WF}_{x}$ is the novel weighting factor for the $x$ th weather index (in Table 2); $M$ is the number of meteorological indices (11 in this study).

The novel assigned weighting factors, which are significant for generating typical meteorological data, are shown in Table 2. A large weighting factor of 0.5 is assigned to global solar radiation because the criteria is mainly used for solar energy systems and the other weather variables (e.g., dry bulb temperature, relative humidity, and atmospheric pressure) are affected by solar radiation. For instance, in general, the higher for the solar radiation, the higher for the dry-bulb temperature. Furthermore, the weighting factor of the mean 
TABLE 2: Meteorological indices and weighting factors for the FS statistic in this study.

\begin{tabular}{lccc}
\hline Number & $\begin{array}{c}\text { Parameter } \\
\text { indices }\end{array}$ & $\begin{array}{c}\text { Present } \\
\text { article }\end{array}$ \\
\hline 1 & Temperature & Max dry bulb temperature & $1 / 24$ \\
2 & & Min dry bulb temperature & $1 / 24$ \\
3 & & Mean dry bulb temperature & $2 / 24$ \\
4 & Humidity & Min relative humidity & $1 / 24$ \\
5 & & Mean relative humidity & $2 / 24$ \\
6 & Wind & Max wind velocity & $1 / 24$ \\
7 & & Mean wind velocity & $2 / 24$ \\
8 & Pressure & Max atmospheric pressure & $1 / 48$ \\
9 & & Min atmospheric pressure & $1 / 48$ \\
10 & & Mean atmospheric pressure & $1 / 24$ \\
11 & Solar & Global solar radiation & $12 / 24$ \\
\hline
\end{tabular}

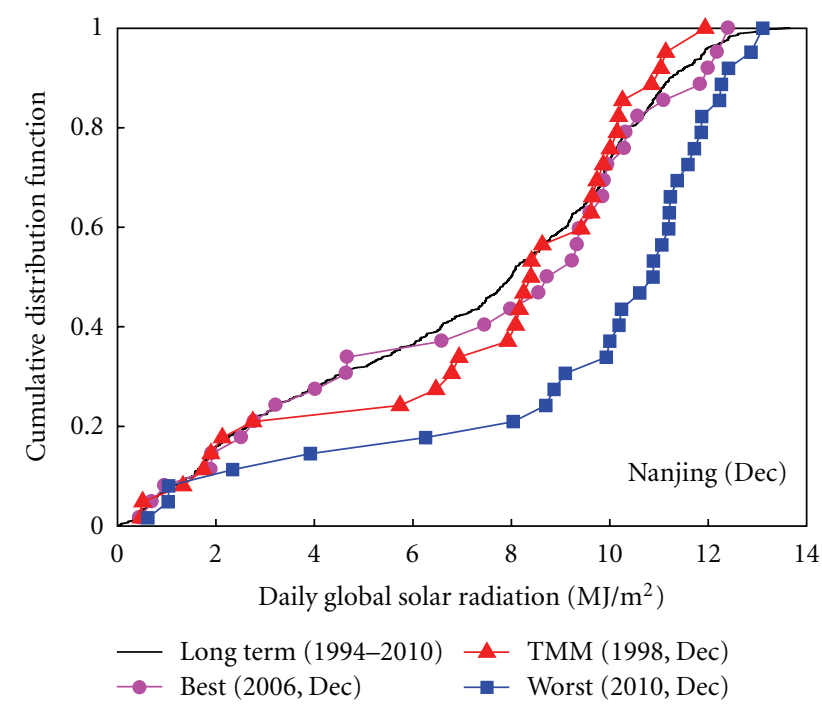

Figure 2: CDFs for December daily global solar radiation for Nanjing.

weather index is larger than that of the max and min weather parameter, for example, 2/24 for Mean Relative Humidity and 1/24 for Min Relative Humidity.

3.2. Final Selection of TMM. The final selection of the TMM from the five candidate years involved a selection process by Pissimanis et al. [29], simpler than the original Sandia method. This method utilizes the root mean square difference (RMSD) of global solar radiation

$$
\operatorname{RMSD}=\left[\frac{\sum_{i=1}^{N}\left(H_{y, m, i}-H_{m a}\right)^{2}}{N}\right]^{1 / 2},
$$

where RMSD is the root mean square difference of global solar radiation; $H_{y, m, i}$ is the daily global solar radiation values of the year $y$, month $m$, and day $i ; H_{m a}$ is mean values of the

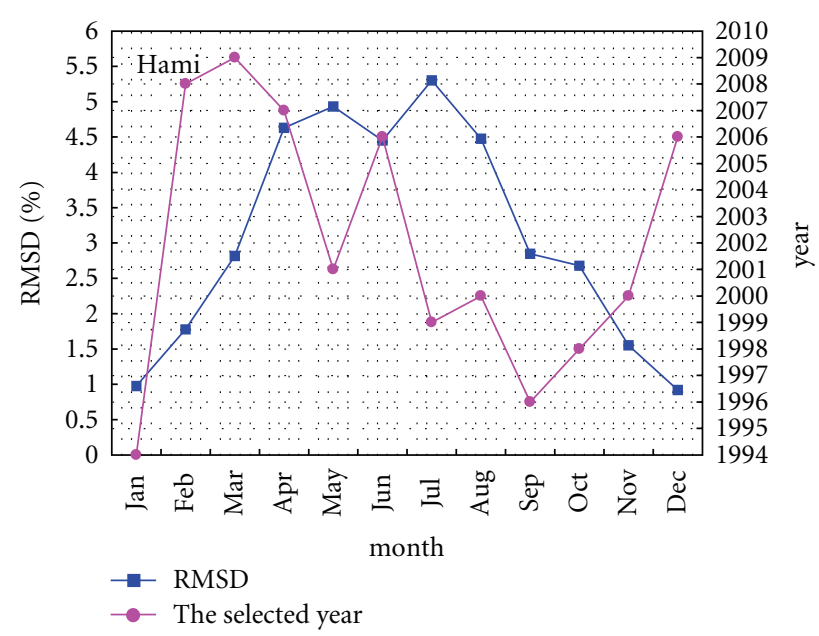

Figure 3: The minimum RMSD and the selected years for each month of the year.

long-term global solar radiation for the month $m ; N$ is the number of daily readings of the month.

Moreover, the month with the minimum RMSD is finally selected as the TMM.

\section{Results and Discussion}

Using the above modified TMY method, the typical meteorological years (TMYs) for the 35 stations listed in Table 1 are generated, consisting of the selected most typical years for 12 months. Furthermore, the detailed typical solar radiation data sourced from the TMYs are analyzed in the following.

Table 3 shows a summary of the TMYs selected for the 35 stations in China. In the final selection, the month with the minimum RMSD of global solar radiation is selected as the TMM. The selected months for creating the TMY of Hami and the minimum RMSD in the corresponding month are shown in Figure 3. From Figure 3, the value of the RMSD of global solar radiation varies between $0.92 \%$ (Dec of 2006) and $5.30 \%$ (Jul of 1999). And it is obviously that several years are used to form the typical months, and data of year 2000 and 2006 are more used than other years in the TMY of Hami.

Although typical solar radiation data obtained from the TMYs are formed for all the 35 stations in the research, owing to space limitations, it is not practical to present all of them in the paper. So, only typical solar radiation data of the Hami station are shown in Figure 4. These data would be useful for the designers of solar energy systems in China. In Figure 4, the maximum and minimum values of daily global radiation data are $30.80 \mathrm{MJ} / \mathrm{m}^{2}$ on July 6 and $3.87 \mathrm{MJ} / \mathrm{m}^{2}$ on December 18 , respectively. Figure 4 shows the variation of typical solar radiation data derived from the TMY data and the long-term (1994-2010) measured data for Hami stations. It can be seen that both the long-term and the typical solar radiation data are variable and fluctuant through the year. Furthermore, typical solar radiation data (green panes) and the long-term recorded data are comparable in size. 
TABLE 3: Summary of the TMYs for the 35 stations in China.

\begin{tabular}{|c|c|c|c|c|c|c|c|c|c|c|c|c|c|}
\hline \multirow[t]{2}{*}{ Number } & \multirow[t]{2}{*}{ Station } & \multicolumn{12}{|c|}{ Month } \\
\hline & & Jan & Feb & Mar & Apr & May & Jun & Jul & Aug & Sep & Oct & Nov & Dec \\
\hline 1 & Beijing & 2007 & 1998 & 2004 & 1996 & 2010 & 1997 & 2001 & 2002 & 2000 & 2004 & 2004 & 2000 \\
\hline 2 & Changchun & 2009 & 1997 & 2006 & 2007 & 1996 & 2001 & 2003 & 2008 & 2006 & 2006 & 2006 & 1999 \\
\hline 3 & Changsha & 2004 & 1997 & 2007 & 2001 & 2004 & 2003 & 2008 & 2000 & 1998 & 2003 & 1999 & 2006 \\
\hline 4 & Chengdu & 1998 & 1998 & 1996 & 2001 & 2002 & 2000 & 2000 & 2002 & 2000 & 2000 & 1999 & 1994 \\
\hline 5 & Dongsheng & 1997 & 2006 & 2000 & 2007 & 1997 & 2006 & 2004 & 2005 & 2000 & 1998 & 2002 & 1999 \\
\hline 6 & Fuzhou & 1999 & 2006 & 1995 & 1997 & 2002 & 1995 & 1998 & 2008 & 1998 & 2007 & 1999 & 1998 \\
\hline 7 & Guangzhou & 1999 & 2003 & 2003 & 2006 & 2001 & 2007 & 2008 & 2003 & 1998 & 1999 & 1999 & 2004 \\
\hline 8 & Guiyang & 1995 & 2002 & 2005 & 2008 & 2001 & 2007 & 2000 & 2007 & 2001 & 2007 & 2004 & 2005 \\
\hline 9 & Haikou & 1994 & 1994 & 2001 & 1998 & 2004 & 2003 & 1998 & 1999 & 2000 & 1996 & 2005 & 1998 \\
\hline 10 & Hami & 1994 & 2008 & 2009 & 2007 & 2001 & 2006 & 1999 & 2000 & 1996 & 1998 & 2000 & 2006 \\
\hline 11 & Hangzhou & 2005 & 1994 & 2004 & 1999 & 1996 & 2000 & 2000 & 2008 & 2001 & 1997 & 2005 & 1998 \\
\hline 12 & Harbin & 2003 & 1998 & 2005 & 1996 & 2001 & 1995 & 1998 & 2009 & 1996 & 2004 & 2009 & 1996 \\
\hline 13 & Hefei & 2003 & 2006 & 2004 & 1997 & 2005 & 2003 & 2008 & 1996 & 2002 & 1994 & 1999 & 2009 \\
\hline 14 & Jiamusi & 2009 & 1997 & 2000 & 2008 & 2001 & 1995 & 2010 & 2008 & 2002 & 2008 & 2009 & 2003 \\
\hline 15 & Jinan & 1997 & 1997 & 2010 & 2007 & 2008 & 2010 & 2007 & 2001 & 1999 & 2005 & 2001 & 2006 \\
\hline 16 & Kashgar & 2005 & 2004 & 2006 & 1998 & 1997 & 2005 & 2001 & 2003 & 2000 & 1998 & 1998 & 1997 \\
\hline 17 & Kunming & 2003 & 1998 & 2001 & 2005 & 1995 & 2004 & 2000 & 1997 & 2005 & 2000 & 1998 & 2000 \\
\hline 18 & Lanzhou & 2000 & 1997 & 2000 & 2000 & 2003 & 1998 & 2002 & 2000 & 2002 & 1998 & 1999 & 2003 \\
\hline 19 & Lhasa & 2001 & 1996 & 2006 & 2008 & 1994 & 1994 & 1996 & 2005 & 2001 & 2000 & 2001 & 2001 \\
\hline 20 & Mohe & 2010 & 1999 & 2006 & 2010 & 2010 & 1999 & 2006 & 2006 & 2007 & 1998 & 2005 & 2006 \\
\hline 21 & Nagqu & 1995 & 2003 & 1995 & 1996 & 2000 & 1999 & 1998 & 2009 & 2008 & 1995 & 1998 & 1994 \\
\hline 22 & Nanchang & 2010 & 1995 & 2004 & 1994 & 1998 & 2007 & 2008 & 2004 & 1996 & 2003 & 1999 & 1998 \\
\hline 23 & Nanjing & 1997 & 1995 & 1995 & 2004 & 1997 & 2007 & 1995 & 1996 & 1996 & 1996 & 2001 & 1998 \\
\hline 24 & Nanning & 2004 & 2002 & 2005 & 2000 & 2002 & 2000 & 2009 & 2004 & 2004 & 2010 & 2003 & 2004 \\
\hline 25 & Sanya & 2002 & 2002 & 2001 & 2003 & 1998 & 2000 & 2000 & 1999 & 2004 & 1995 & 2002 & 1996 \\
\hline 26 & Shanghai & 1997 & 1997 & 2004 & 2008 & 2000 & 1998 & 1998 & 2004 & 2003 & 1997 & 1999 & 1998 \\
\hline 27 & Shenyang & 2009 & 1997 & 2004 & 2007 & 2006 & 1996 & 2005 & 2002 & 1995 & 2006 & 2006 & 1999 \\
\hline 28 & Taiyuan & 1996 & 1995 & 2006 & 2006 & 2005 & 1998 & 1995 & 2009 & 2006 & 1999 & 2001 & 2003 \\
\hline 29 & Tianjin & 2009 & 1999 & 2000 & 2004 & 2002 & 1997 & 2005 & 2002 & 1999 & 1999 & 2004 & 1999 \\
\hline 30 & Urumqi & 1999 & 1996 & 2007 & 2004 & 2005 & 2006 & 1994 & 1995 & 2005 & 2008 & 2006 & 1996 \\
\hline 31 & Wuhan & 1996 & 2000 & 2009 & 2001 & 1997 & 2003 & 2005 & 1995 & 2004 & 2008 & 1999 & 1998 \\
\hline 32 & Xian & 1996 & 1996 & 1999 & 1995 & 1997 & 2003 & 2000 & 1999 & 1999 & 1996 & 2004 & 1998 \\
\hline 33 & Xining & 2000 & 2001 & 2010 & 2000 & 2005 & 2009 & 2007 & 2002 & 2006 & 2008 & 2007 & 1997 \\
\hline 34 & Yinchuan & 1998 & 2003 & 2000 & 2003 & 1997 & 2006 & 2001 & 1997 & 1999 & 2003 & 1999 & 2003 \\
\hline 35 & Zhengzhou & 1997 & 1998 & 1995 & 1995 & 1997 & 1998 & 2002 & 1995 & 2000 & 2008 & 2001 & 1998 \\
\hline
\end{tabular}

In order to find out which years tend to follow the longterm weather patterns more closely than the others, the selected TMYs listed in Table 3 are investigated. The year selection frequency for the TMYs derived from the period of 19942010 is shown in Figure 5. In Figure 5, it is apparently that the frequency occurrence of the year 1998 is up to $9.52 \%$ and the year 2010 is only $2.38 \%$. For intensive study, Table 4 gives a summary of the times which the year is selected as the TMM. Obviously, 1998 and 2010 are the most frequent year (40 times) and the least frequent year (10 times), respectively. In each year during the period 1994-2010, the number of the times vary from one month to another and 10 (November of 1999) is the largest selected number. In other words, no more than 10 stations are selected for the same month in any particular year.

In addition, the accuracy of TMY data is excellent on monthly bases. Figures 6 and 7 show the monthly mean values of the actual dry bulb temperature and global solar radiation for eight stations (Guangzhou, Lhasa, Hangzhou, Chengdu, Lanzhou, Tianjin, Hami, Harbin), respectively. There are three monthly profiles in Figures 6 and 7, which are determined by the long-term (1994-2010), the selected TMMs, and the worst months (the month with the largest RMSD value in the final selection of TMM). From Figures 6 and 7 , it can be concluded that the monthly mean daily dry bulb temperature and global solar radiation derived from 
TABLE 4: Frequency of a year being selected to provide a TMM.

\begin{tabular}{lccccccccccccc}
\hline Year & Jan & Feb & Mar & Apr & May & Jun & Jul & Aug & Sep & Oct & Nov & Dec & Total times \\
\hline 1994 & 2 & 2 & 0 & 1 & 1 & 1 & 1 & 0 & 0 & 1 & 0 & 2 & 11 \\
1995 & 2 & 3 & 4 & 2 & 1 & 3 & 2 & 3 & 1 & 2 & 0 & 0 & 23 \\
1996 & 3 & 3 & 1 & 3 & 2 & 1 & 1 & 2 & 4 & 3 & 0 & 3 & 26 \\
1997 & 5 & 7 & 0 & 2 & 7 & 2 & 0 & 2 & 0 & 2 & 0 & 2 & 29 \\
1998 & 2 & 5 & 0 & 2 & 2 & 4 & 5 & 0 & 3 & 5 & 3 & 9 & 40 \\
1999 & 3 & 2 & 1 & 1 & 0 & 2 & 1 & 3 & 4 & 3 & 10 & 4 & 34 \\
2000 & 2 & 1 & 5 & 3 & 2 & 4 & 6 & 3 & 6 & 3 & 1 & 2 & 38 \\
2001 & 1 & 1 & 3 & 3 & 5 & 1 & 3 & 1 & 3 & 0 & 5 & 1 & 27 \\
2002 & 1 & 3 & 0 & 0 & 4 & 0 & 2 & 5 & 3 & 0 & 2 & 0 & 20 \\
2003 & 3 & 3 & 1 & 2 & 1 & 5 & 1 & 2 & 1 & 3 & 1 & 4 & 27 \\
2004 & 2 & 1 & 6 & 3 & 2 & 1 & 1 & 3 & 3 & 2 & 4 & 2 & 30 \\
2005 & 2 & 0 & 3 & 1 & 4 & 1 & 3 & 2 & 2 & 1 & 3 & 1 & 23 \\
2006 & 0 & 3 & 5 & 2 & 1 & 4 & 1 & 1 & 3 & 2 & 3 & 4 & 29 \\
2007 & 1 & 0 & 2 & 5 & 0 & 4 & 2 & 1 & 1 & 2 & 1 & 0 & 19 \\
2008 & 0 & 1 & 0 & 4 & 1 & 0 & 4 & 4 & 1 & 5 & 0 & 0 & 20 \\
2009 & 4 & 0 & 2 & 0 & 0 & 1 & 1 & 3 & 0 & 0 & 2 & 1 & 14 \\
2010 & 2 & 0 & 2 & 1 & 2 & 1 & 1 & 0 & 0 & 1 & 0 & 0 & 10 \\
\hline
\end{tabular}

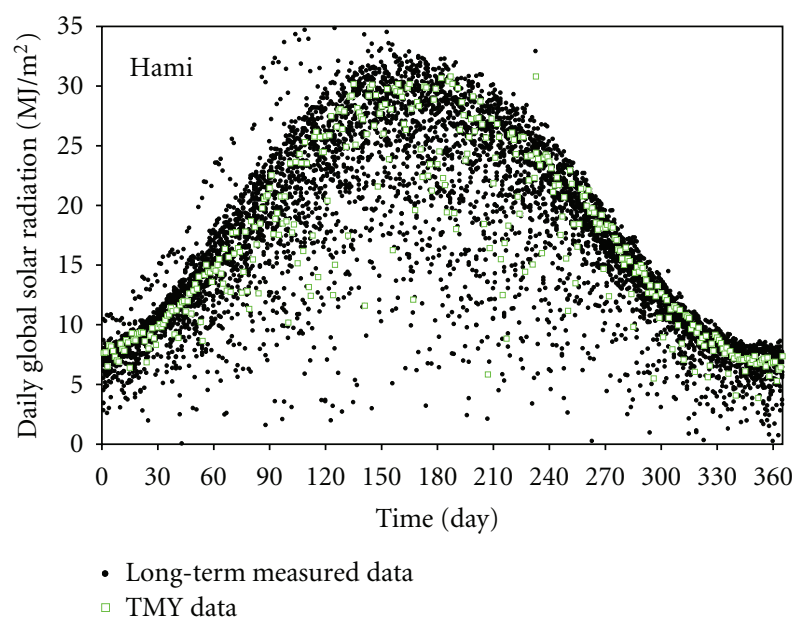

FIgURE 4: Variation of typical solar radiation data and long-term (1994-2010) measured data for Hami station.

the TMY data represent good agreement with the long-term recorded average data. Moreover, in Figure 7, in general, the difference between the long-term measured data with the TMY data is smaller than that of the worst months.

\section{Conclusions}

Typical solar radiation data are the key elements for the applications of solar energy systems and building energy simulation. A modified TMY method using the FinkelsteinSchafer statistical to generate TMY data from the long-term measured weather database is implemented at 35 stations in China. In particular, eleven weather indices and the novel assigned weighting factors are proposed and applied in this research.

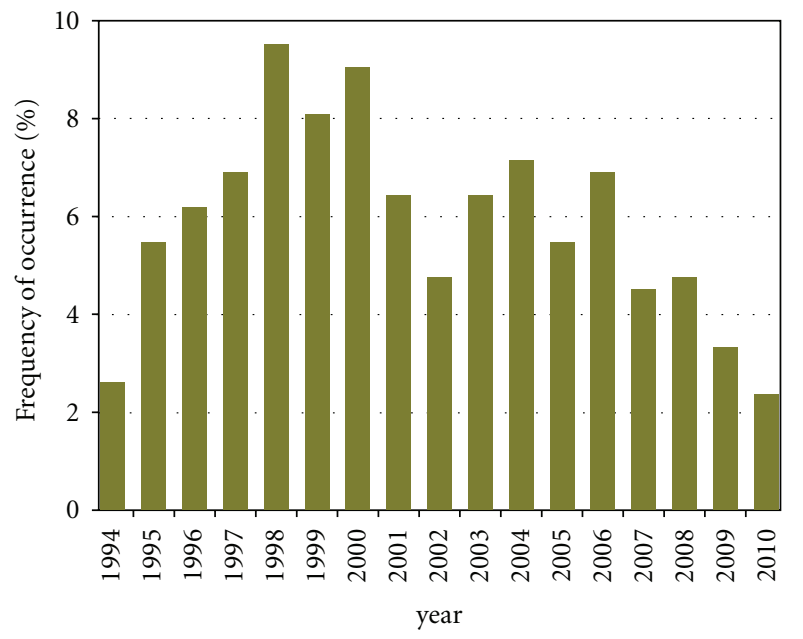

FIGURE 5: Summary of year selection frequency for 1994-2010 TMY.

TMYs for 35 stations in China are investigated and generated based on the accurate and the most recent long-term (1994-2010) measured weather data, such as dry bulb temperature, relative humidity, wind velocity, atmospheric pressure, and daily global solar radiation. Typical solar radiation data obtained from the TMY data, with Hami as an example, are presented and analyzed in this study. It is found that the global solar radiation cumulative distribution functions (CDFs) of the selected TMMs tend to follow their long-term counterparts well. It is also seen that the year 1998 follows the long-term weather patterns more closely than the others. Moreover, there is a good agreement between the typical solar radiation data and the long-term measured data on monthly basis. 


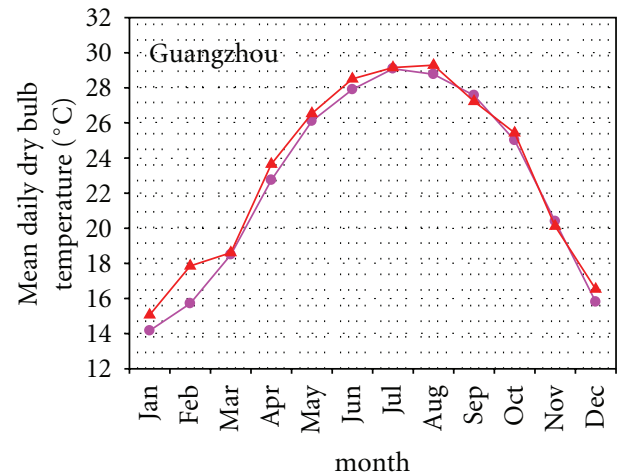

(a)

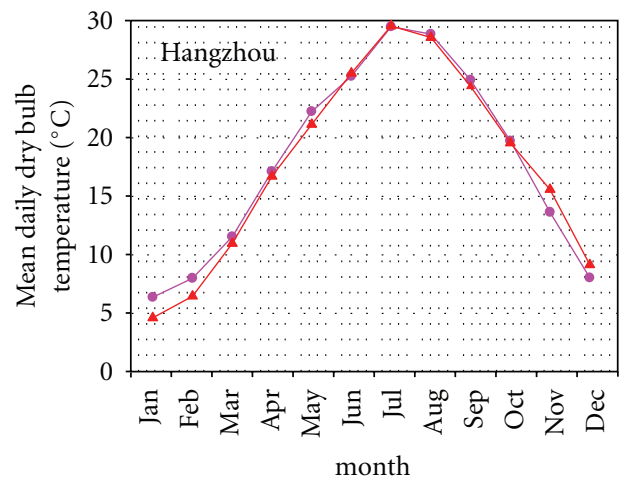

(c)

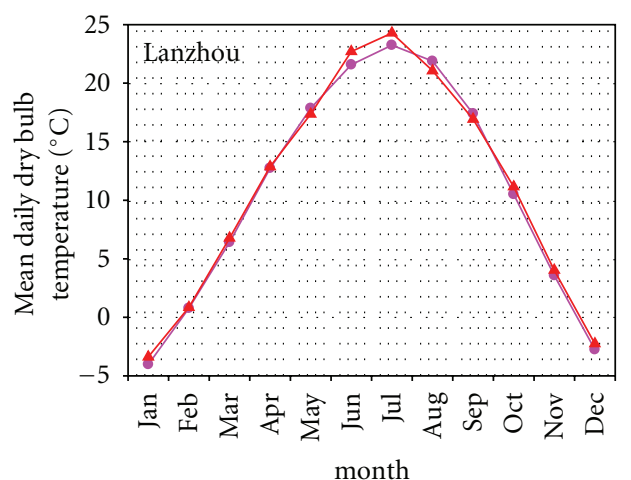

(e)

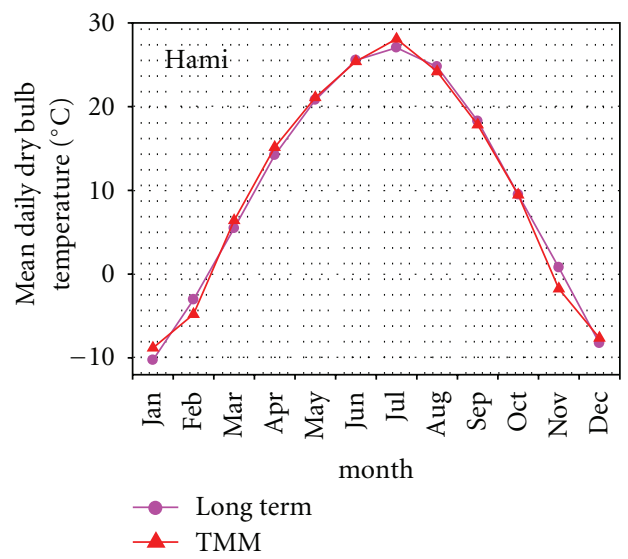

(g)

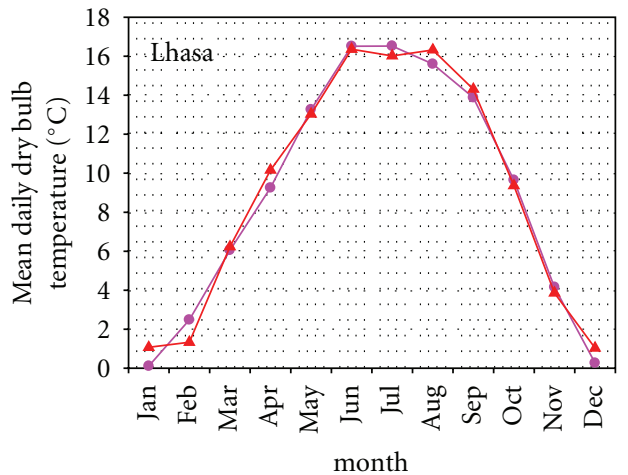

(b)

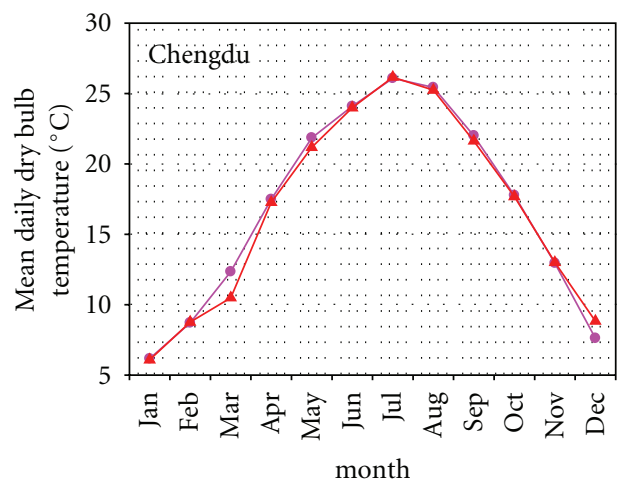

(d)

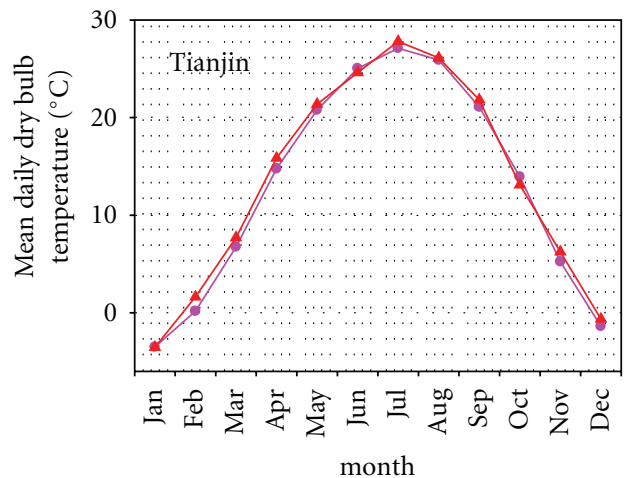

(f)

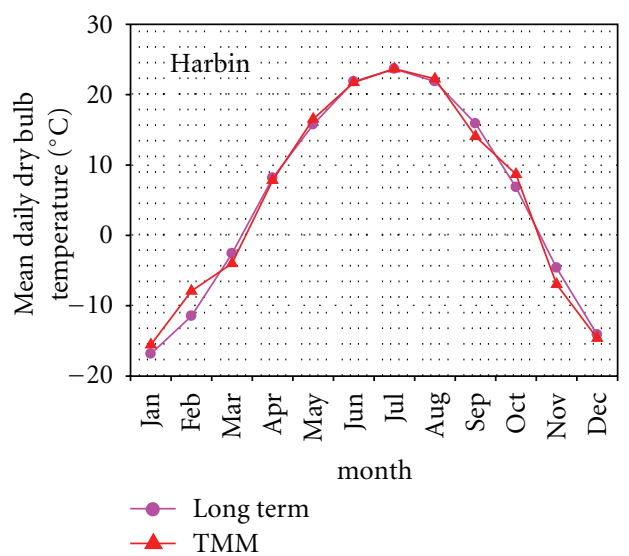

(h)

FIGURE 6: Monthly mean daily dry bulb temperature for the long-term and for the selected TMMs at eight stations. 


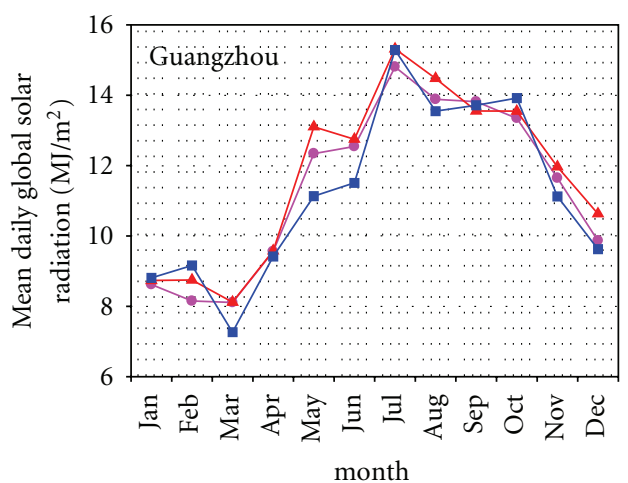

(a)

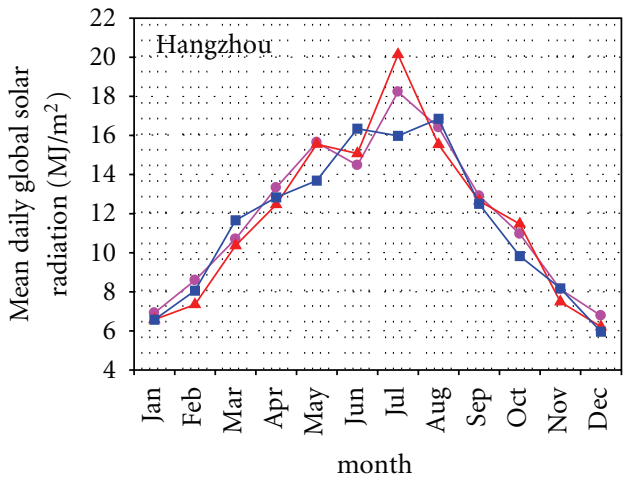

(c)

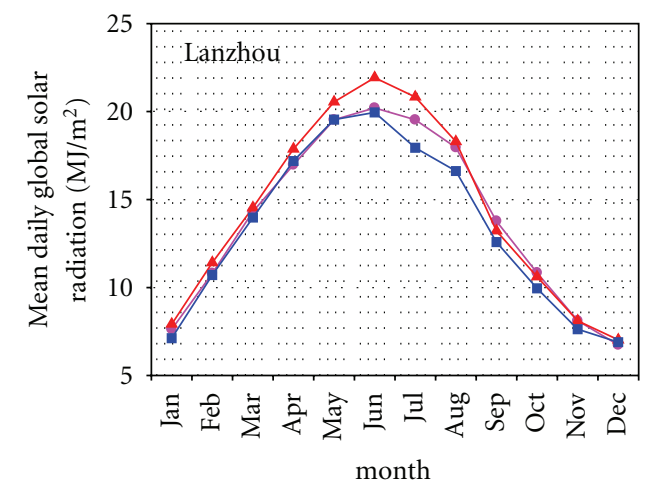

(e)

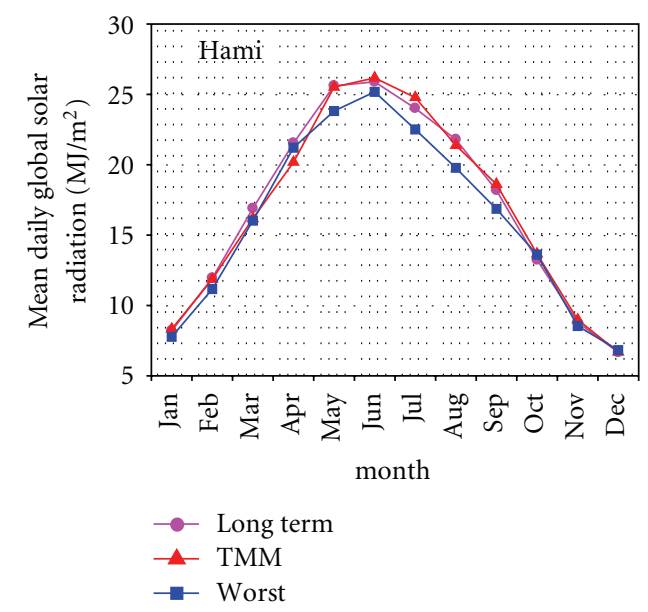

(g)

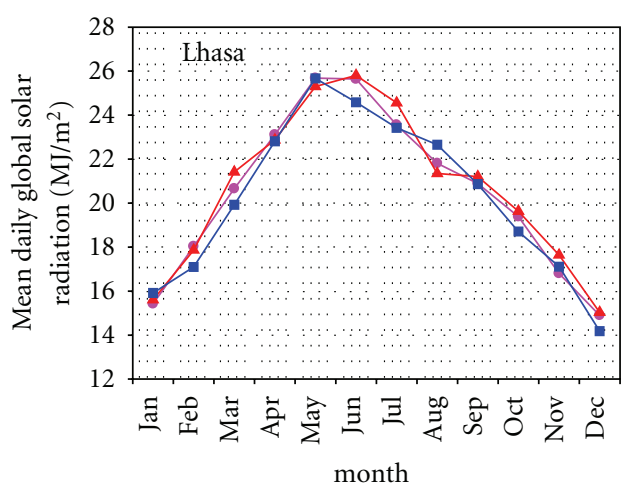

(b)

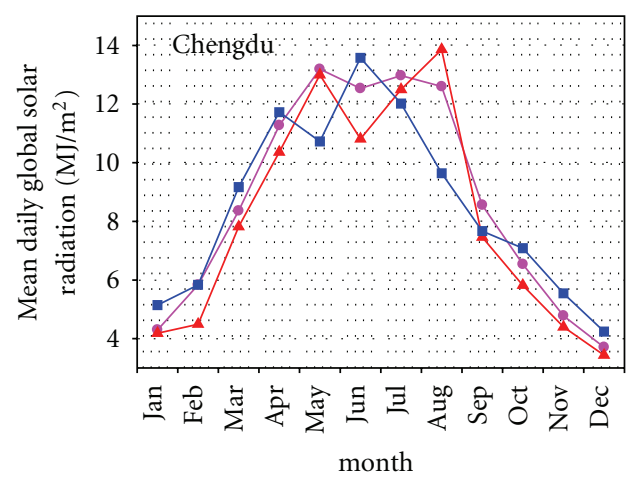

(d)

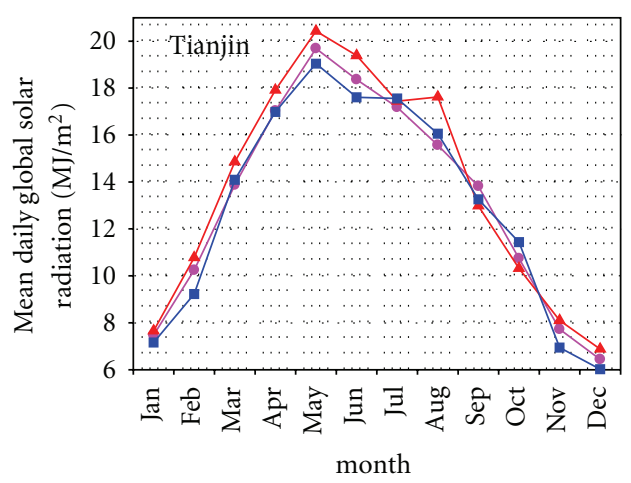

(f)

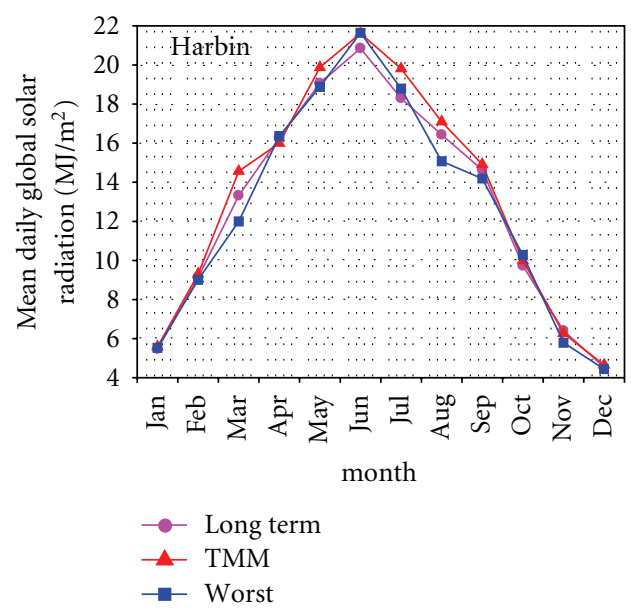

(h)

FIgURE 7: Monthly mean daily global solar radiation for the long-term, for the selected TMMs, and for the worst months at eight stations. 
It is expected that the TMY data and typical soar radiation data generated in this paper will exert positive effects on some energy-related scientific researches and engineering applications in China. Future researches will focus on the TMY data and typical solar radiation data on a larger regional scale. We hope to report on these works in the near future.

\section{Acknowledgments}

The research is financially supported by National Natural Science Foundation of China (Program no. 50907010), Research and Innovation Project for College Postgraduates of Jiangsu Province (Program no. CXLX11_0112), and The Scientific Research Foundation of Graduate School of Southeast University (YBJJ1132). The authors would like to thank the National Meteorological Information Centre, China Meteorological administration. They are also grateful to the anonymous reviewer for his/her constructive comments and suggestions on this paper.

\section{References}

[1] L. Q. Liu, Z. X. Wang, H. Q. Zhang, and Y. C. Xue, "Solar energy development in China-a review," Renewable and Sustainable Energy Reviews, vol. 14, no. 1, pp. 301-311, 2010.

[2] L. Q. Liu and Z. X. Wang, "The development and application practice of wind-solar energy hybrid generation systems in China," Renewable and Sustainable Energy Reviews, vol. 13, no. 6-7, pp. 1504-1512, 2009.

[3] Z. S. Li, G. Q. Zhang, D. M. Li, J. Zhou, L. J. Li, and L. X. Li, "Application and development of solar energy in building industry and its prospects in China," Energy Policy, vol. 35, no. 8, pp. 4121-4127, 2007.

[4] Z. Jin, W. Yezheng, and Y. Gang, "Estimation of daily diffuse solar radiation in China," Renewable Energy, vol. 29, no. 9, pp. 1537-1548, 2004.

[5] Y.-T. Cheng, J.-J. Ho, W. Lee et al., "Efficiency improved by $\mathrm{H}_{2}$ forming gas treatment for Si-based solar cell applications," International Journal of Photoenergy, vol. 2010, Article ID 634162, 6 pages, 2010.

[6] M. Taherbaneh, A. H. Rezaie, H. Ghafoorifard, K. Rahimi, and M. B. Menhaj, "Maximizing output power of a solar panel via combination of sun tracking and maximum power point tracking by fuzzy controllers," International Journal of Photoenergy, vol. 2010, Article ID 312580, 13 pages, 2010.

[7] H. Li, W. Ma, Y. Lian, and X. Wang, "Estimating daily global solar radiation by day of year in China," Applied Energy, vol. 87, no. 10, pp. 3011-3017, 2010.

[8] L. J. Guo, L. Zhao, D. W. Jing et al., "Solar hydrogen production and its development in China," Energy, vol. 34, no. 9, pp. 1073-1090, 2009.

[9] J. Zhou, Y. Wu, and G. Yan, "Generation of typical solar radiation year for China," Renewable Energy, vol. 31, no. 12, pp. 1972-1985, 2006.

[10] D. H. W. Li and T. N. T. Lam, "Determining the optimum tilt angle and orientation for solar energy collection based on measured solar radiance data," International Journal of Photoenergy, vol. 2007, Article ID 85402, 9 pages, 2007.

[11] A. A. Sabziparvar, "General formula for estimation of monthly mean global solar radiation in different climates on the south and north coasts of Iran," International Journal of Photoenergy, vol. 2007, Article ID 94786, 7 pages, 2007.

[12] H. Bulut, "Generation of representative solar radiation data for Aegean region of Turkey," International Journal of Physical Sciences, vol. 5, no. 7, pp. 1124-1131, 2010.

[13] H. Bulut, O. Büyükalaca, and A. Yilmaz, "Generation of typical solar radiation year for Mediterranean region of Turkey," International Journal of Green Energy, vol. 6, no. 2, pp. 173-183, 2009.

[14] Y. Jiang, "Generation of typical meteorological year for different climates of China," Energy, vol. 35, no. 5, pp. 1946-1953, 2010.

[15] A. Argiriou, S. Lykoudis, S. Kontoyiannidis et al., "Comparison of methodologies for TMY generation using 20 years data for Athens, Greece," Solar Energy, vol. 66, no. 1, pp. 33-45, 1999.

[16] J. Bilbao, A. Miguel, J. A. Franco, and A. Ayuso, "Test reference year generation and evaluation methods in the continental Mediterranean area," Journal of Applied Meteorology, vol. 43, no. 2, pp. 390-400, 2004.

[17] A. de Miguel and J. Bilbao, "Test reference year generation from meteorological and simulated solar radiation data," Solar Energy, vol. 78, no. 6, pp. 695-703, 2005.

[18] R. Festa and C. F. Ratto, "Proposal of a numerical procedure to select reference years," Solar Energy, vol. 50, no. 1, pp. 9-17, 1993.

[19] I. J. Hall, R. R. Prairie, H. E. Anderson, and E. C. Boes, "Generation of a typical meteorological year," in Proceedings of the Annual Meeting of the American Society of the International Solar Energy Society, Calif, USA, June 1978.

[20] K. Skeiker, "Comparison of methodologies for TMY generation using 10 years data for Damascus, Syria," Energy Conversion and Management, vol. 48, no. 7, pp. 2090-2102, 2007.

[21] S. A. M. Said and H. M. Kadry, "Generation of representative weather-year data for Saudi Arabia," Applied Energy, vol. 48, no. 2, pp. 131-136, 1994.

[22] W. Marion and K. Urban, User Manual for TMY2s-Typical Meteorological Years Derived from the 1961-1990 National Solar Radiation Data Base, National Renewable Energy Laboratory,Inc., 1995.

[23] M. Petrakis, H. D. Kambezidis, S. Lykoudis et al., "Generation of a "typical meteorological year" for Nicosia, Cyprus," Renewable Energy, vol. 13, no. 3, pp. 381-388, 1998.

[24] S. A. Kalogirou, "Generation of typical meteorological year (TMY-2) for Nicosia, Cyprus," Renewable Energy, vol. 28, no. 15, pp. 2317-2334, 2003.

[25] T. T. Chow, A. L. S. Chan, K. F. Fong, and Z. Lin, "Some perceptions on typical weather year-from the observations of Hong Kong and Macau," Solar Energy, vol. 80, no. 4, pp. 459467, 2006.

[26] S. Wilcox and W. Marion, Users Manual for TMY3 Data Sets, National Renewable Energy Laboratory,Inc., 2008.

[27] L. Yang, J. C. Lam, and J. Liu, "Analysis of typical meteorological years in different climates of China," Energy Conversion and Management, vol. 48, no. 2, pp. 654-668, 2007.

[28] J. M. Finkelstein and R. E. Schafer, "Improved goodness-of-fit tests," Biometrika, vol. 58, no. 3, pp. 641-645, 1971.

[29] D. Pissimanis, G. Karras, V. Notaridou, and K. Gavra, “The generation of a "typical meteorological year" for the city of Athens," Solar Energy, vol. 40, no. 5, pp. 405-411, 1988. 


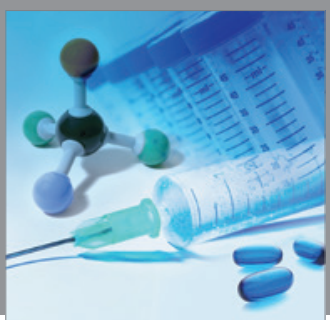

International Journal of

Medicinal Chemistry

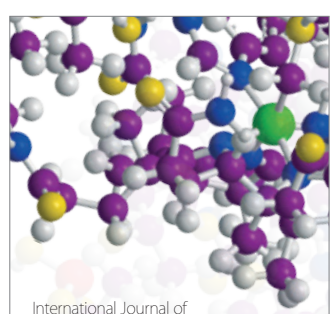

Carbohydrate Chemistry

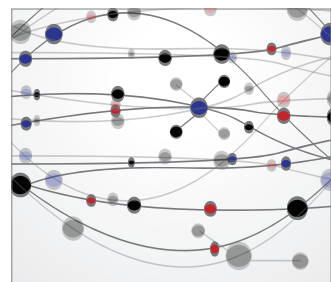

The Scientific World Journal
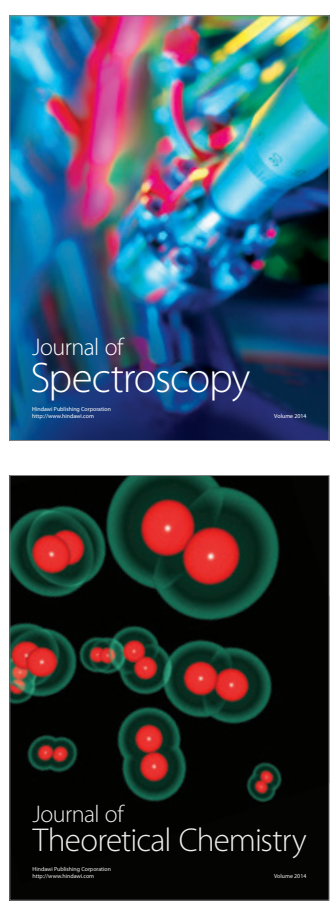
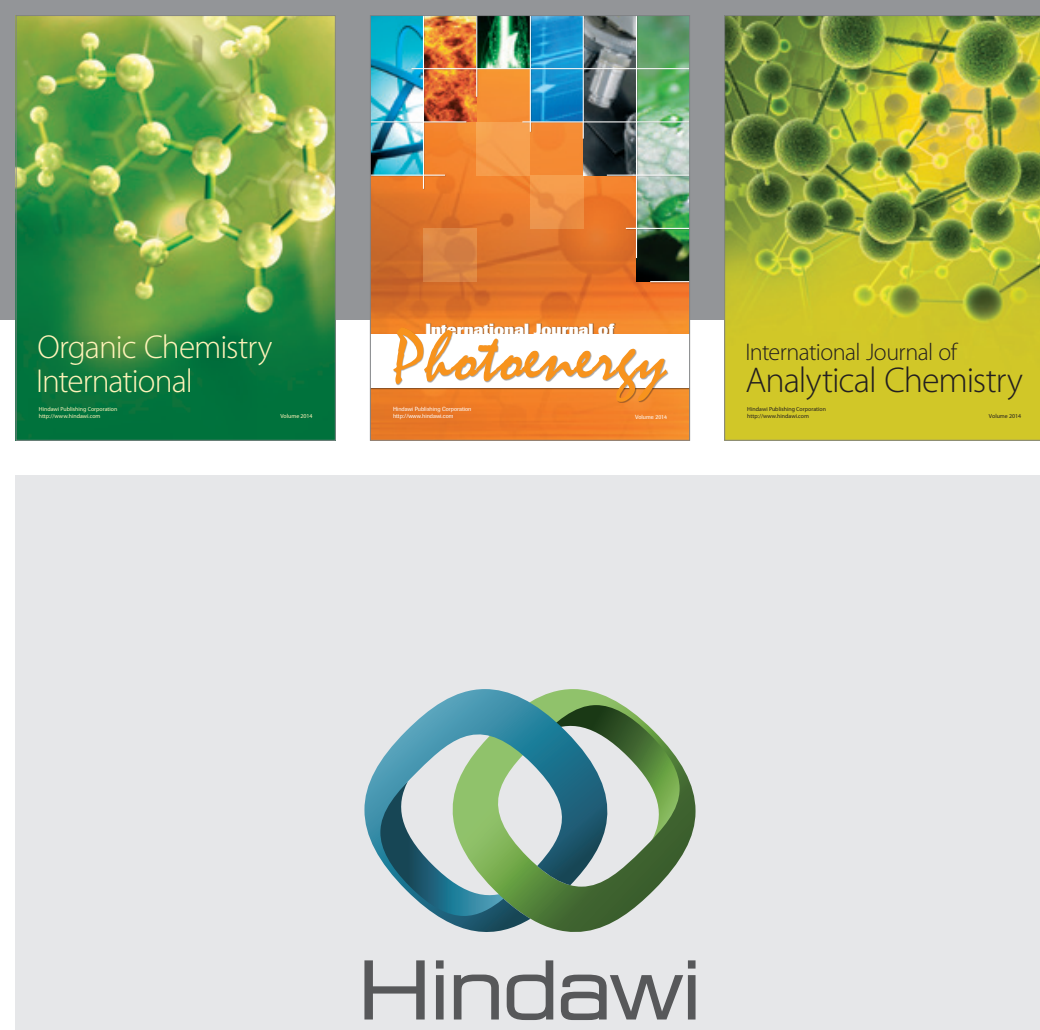

Submit your manuscripts at

http://www.hindawi.com
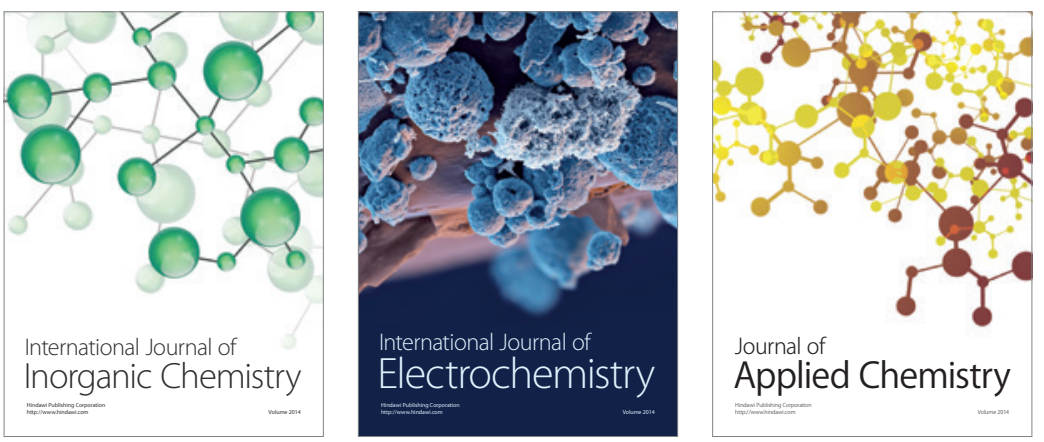

Journal of

Applied Chemistry
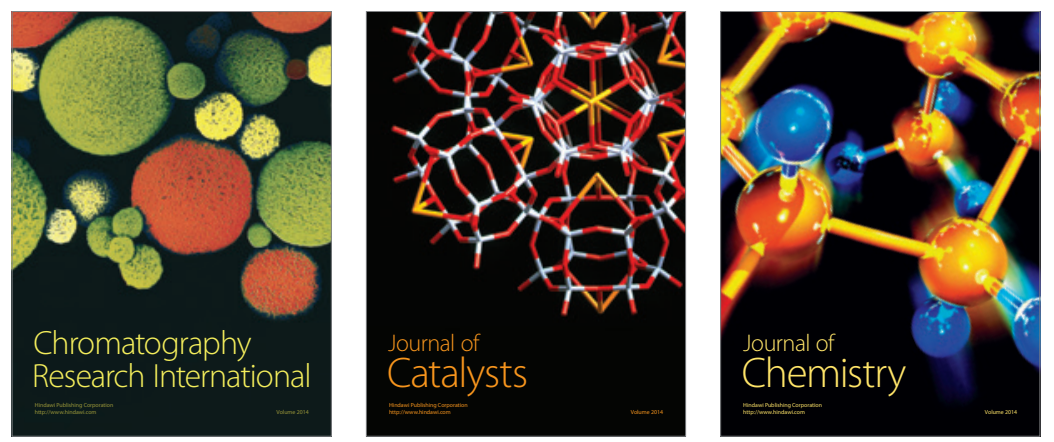
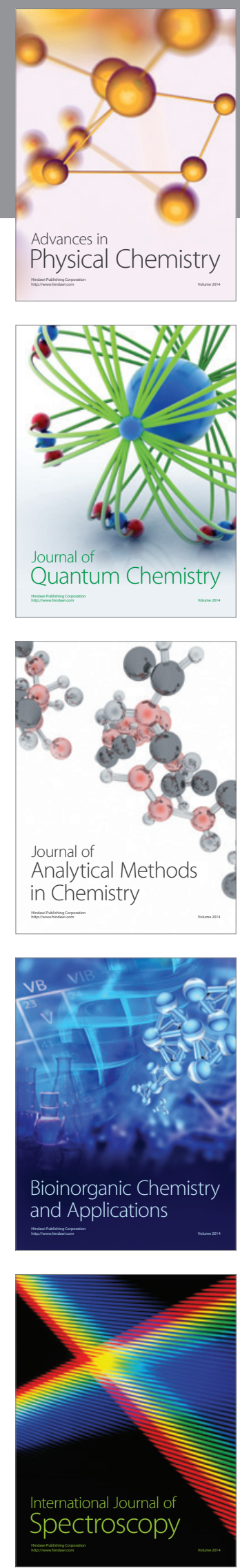